\title{
Protein profile of Chlamydophila abortus isolates from Kerala, I ndia
}

\author{
Binu K Mani ${ }^{1}, \mathrm{M} \mathrm{Mini}^{2}, \mathrm{~V} \mathrm{~N}$ Vasudevan ${ }^{3}$ \\ ${ }^{1}$ Assistant Professor, ${ }^{2}$ Professor, Department of Veterinary Microbiology, \\ ${ }^{3}$ Assistant Professor Department of Livestock Products Technology, \\ College of Veterinary \& Animal Sciences, Mannuthy, Thrissur, Kerala, India, 680651. \\ Corresponding author e-mail: binukmani@yahoo.com
}

Received: 18-04-2011, Accepted: 28-04-2011, Published Online: 05-09-2011

doi: $10.5455 /$ vetworld.2011.470-472

\begin{abstract}
Chlamydiae are of microbiological interest because of their mode of interaction with eukaryotic host cells and their specialized life cycle with unique features of parasitism. Reports regarding prevalence of infections of Chlamydophila abortus, the causative organism for chlamydial abortions in livestock, was the basis of the study. Two isolates, one each from cattle and goat abortion along with a reference isolate, were used for characterization with Sodium Dodecyl Sulphate-Poly Acrylamide Gel Electrophoresis (SDS-PAGE). Elementary bodies infected Mc Coy cells, harvested from bottle cultures were disrupted by Teflon coated magnetic pellet. Urografin-76 diluted with Tris-Potassium hydrochloride was used for purification of Elementary bodies of Chlamydophila abortus organism. On protein estimation of Elementary bodies by Biuret method, all the three isolates revealed protein concentration between $500-1000 \mathrm{mg} / 100 \mathrm{ml}$, which were sufficient for electrophoresis. Ten percent of resolving gel and five percent of stacking gel of polyacrylamide in which $10 \mathrm{~g}$ of processed isolate samples along with standard protein marker and Mc Coy cell protein (control) were electrophoresed. Using Alpha Imager Gel Documentation System, the protein bands were analyzed. Twelve bands each for local bovine isolate and reference isolate were noticed while only 10 bands were there in the caprine isolate. Additional bands of $148 \mathrm{kDa}$ and $135 \mathrm{kDa}$ were present in bovine isolate, compared to the reference isolate, while $152 \mathrm{kDa}$ and $137 \mathrm{kDa}$ bands were unique for caprine isolate.
\end{abstract}

Key words: Chlamydophila abortus, protein profile, Mc Coy cell, elementary bodies

\section{I ntroduction}

Chlamydial organism causes economically important diseases such as pneumonitis, polyarthritis, enteritis, encephalomyelitis, conjunctivitis and placentitis leading to abortion in domestic animals (Storz, 1971). Research work carried out in India had proved the prevalence of chlamydial agents in the northern states of India (Batta et al., 1996 and Katoch, 1997). In Kerala, Chlamydial organism had been isolated from pneumonic lungs in goats, aborted foetus and semen samples from bovines (Francis, 1988 and Mani et al., 2006). Based on latest classification two genera named Chlamydia and Chlamydophila comes under family Chlamydiaceae. The organisms that cause abortion in ruminants have been characterized as Chlamydophila abortus. The present study was to compare and understand the protein profile of two local isolates of Chlamydophila abortus based on a reference isolate from Department of Veterinary Microbiology, Veterinary College, Palampur, Himachal Pradesh.

\section{Materials and Methods}

Chlamydial organisms isolated from bovine and caprine abortion samples were the materials for the study. The primary isolation was done by inoculating the suspected samples in chick embryo through Yolk sac route. The identity of the local samples with the reference isolate was confirmed by Agar Gel Precipitation Test and sensitivity for sodium sulphadiazine (Mani et al., 2006).

The samples were inoculated in Mc Coy cell culture for the purpose of purification of elementary bodies (EBs) of the organism. Chlamydial cell culture harvests of $100 \mathrm{ml}$ were disrupted using Teflon coated magnetic pellet for 5 minutes at $4^{\circ} \mathrm{C}$ to remove cell debris. The supernatant was layered on to $30 \%$ (v/v) urografin-76 diluted with Tris-Potassium hydrochloride $(\mathrm{T}-\mathrm{KCl})$. Centrifuged at $50000 \mathrm{x} \mathrm{g}$ for 45 minutes and pellet was re-suspended in one milliliter of T-KCl. It was layered on to 30 to 60 percent $(\mathrm{v} / \mathrm{v})$ urografin- 76 gradient in $\mathrm{T}-\mathrm{KCl}$ and then centrifuged at $50000 \mathrm{x} g$ for two hours. The band seen at the middle of 

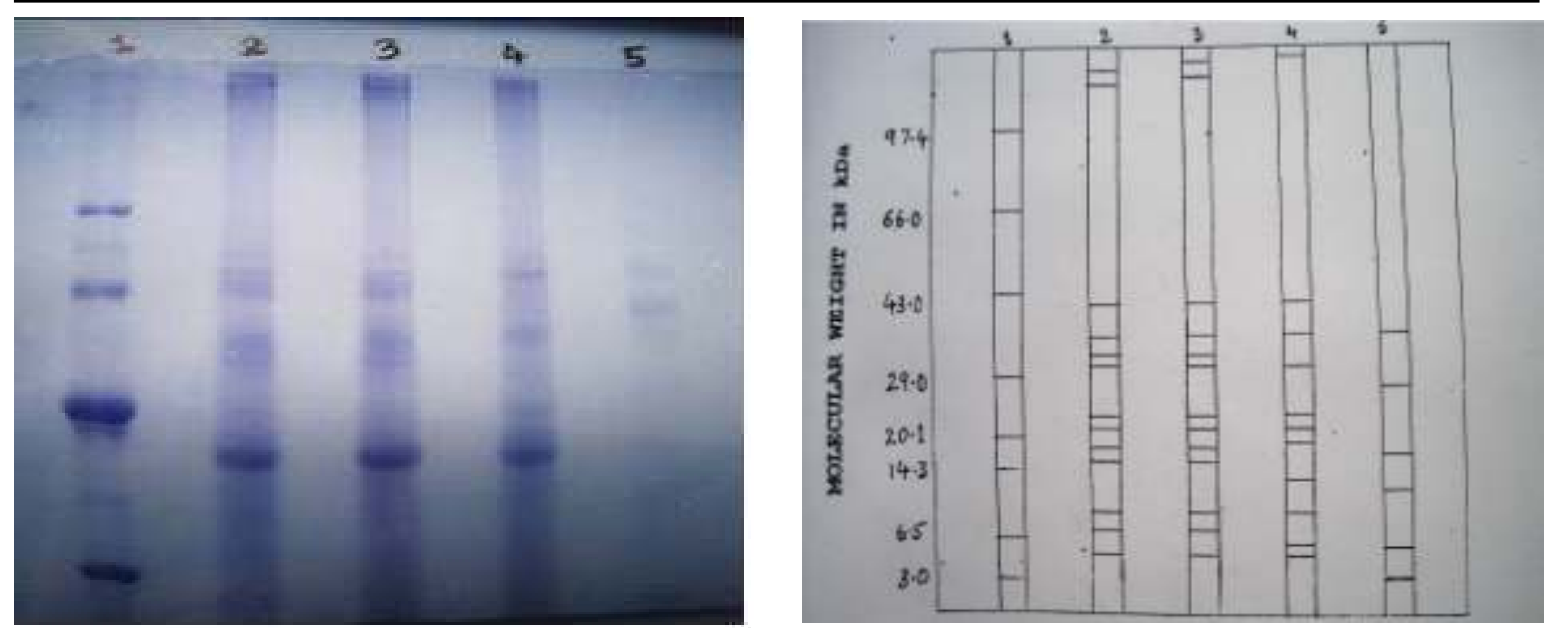

A - Coomassie brilliant blue stained gel after SDS-PAGE

B - Representation of protein bands on each well analysed by Alpha I mager Gel Documentation System;

1- Marker, 2- Reference strain, 3- Bovine isolate, 4- caprine isolate, 5- Mc Coy cell protein.

the 40 and 50 percent gradient was collected, diluted with three millilitres of $\mathrm{T}-\mathrm{KCl}$ and centrifuged again at $50000 \mathrm{x} \mathrm{g}$ for 45 minutes. The pellet was resuspended in $0.5 \mathrm{ml}$ of $\mathrm{T}-\mathrm{KCl}$. This was taken as purified EBs of Chlamydophila abortus isolates. Fifty milliltres of uninfected Mc Coy cell harvest was disrupted with a teflon coated magnetic pellet. This was sonicated at $40 \%$ duty cycle for 5 minutes at $4^{\circ} \mathrm{C}$ in Branson sonifier 450 using microtip. This was used as the cell control. The protein estimation of EBs was done by Biuret method, using Protein Estimation Kit.

Sodium dodecyl sulphate - poly acrylamide gel electrophoresis (SDS-PAGE) was used for characterization of protein fractions of different Chlamydophila abortus isolates, following the procedures described by Laemmli (1970). Sample containing about $10 \mathrm{~g}$ of purified elementary body was mixed with equal volume of sample buffer, heated in a water bath at $90^{\circ} \mathrm{C}$ for one minute, cooled and stored at $4^{\circ} \mathrm{C}$. The cell protein was also prepared as above.

The discontinuous system of polyacrylamide gel electrophoresis was employed (Markey et al., 1993). One millimetre thick spacer was used for separating the glass plates. A $10 \%$ and $5 \%$ of gels were casted as resolving and stacking gel respectively. Wells of the gel were loaded with $20 \mu \mathrm{l}$ of each of the above prepared samples. The standard protein marker ( $3 \mathrm{kDa}$ to 97.4 $\mathrm{kDa}$ ) was from Genei Bangalore. A voltage of $150 \mathrm{~V}$ was used for the electrophoresis. The gel was stained with coomassie brilliant blue by standard procedure. Using Alpha Imager Gel Documentation System, the protein bands were analyzed and photographed.

\section{Results and Discussion}

Those isolates confirmed with sodium sulpha diazine treatment and Agar gel Precipitation Test, were used for studying the protein profile. All the three isolates revealed protein concentration between 500 $1000 \mathrm{mg} / 100 \mathrm{ml}$, which were sufficient for electrophoresis. After electrophoresis the polypeptide bands were clearly visible on staining with coomassie brilliant blue.

Control well showed six bands, of which the band at $36 \mathrm{kDa}$ was present in all the three isolates and so was not taken in to account. Thus a total of 12 protein bands were observed in the reference and bovine isolates. Of the 12 bands observed most of them were common. Additional bands of molecular weight $148 \mathrm{kDa}$ and $135 \mathrm{kDa}$ were present in reference isolate, while $152 \mathrm{kDa}$ and $137 \mathrm{kDa}$ were unique for local bovine sample. Ten bands only were noticed in the local caprine sample and were lacking bands at ranges of $152 \mathrm{kDa}, 148 \mathrm{kDa}, 137 \mathrm{kDa}, 135 \mathrm{kDa}, 32$ $\mathrm{kDa}, 18 \mathrm{kDa}, 15 \mathrm{kDa}$ and $7 \mathrm{kDa}$. Bands of $155 \mathrm{kDa}, 19$ $\mathrm{kDa}, 12.2 \mathrm{kDa}$ and $6.4 \mathrm{kDa}$ were present only in caprine sample.

In the present study only 12 polypeptide bands were prominent in both the bovine isolates while 10 bands were present for caprine isolate. Eventhough the reference and bovine isolates gave same number of bands, the bands at molecular weights $148 \mathrm{kDa}$ and $135 \mathrm{kDa}$ were unique for the reference isolate. 152 $\mathrm{kDa}$ and $137 \mathrm{kDa}$ were seen only in local bovine isolate. In local caprine isolate $155 \mathrm{kDa}, 19 \mathrm{kDa}, 12.2$ $\mathrm{kDa}$ and $6.4 \mathrm{kDa}$ bands were unique. Six bands of 
molecular weights $42 \mathrm{kDa}, 30 \mathrm{kDa}, 23 \mathrm{kDa}, 21 \mathrm{kDa}, 9$ $\mathrm{kDa}$ and $5 \mathrm{kDa}$ were common for both bovine and caprine isolates.

\section{Acknowledgements}

Authors are thankful to the Indian Council of Agricultural Research for funding the project of "Chlamydiosis in livestock with special reference to abortion in livestock".

\section{References}

1. Batta, M.K., Sharma, M., Asrani, R.K., Katoch, R.C. and Joshi, V.B. (1996). Investigations on abortion outbreaks in migratory sheep and goats of Himachal Pradesh. Indian Vet. J.73: 432 .

2. Francis, R. (1988). Prevalence of chlamydial agents in livestock in Kerala. M.V.Sc. thesis, Kerala Agricultural University.
3. Katoch, R.C. (1997). Epidemiology and immunodiagnosis of Chlamydia psittaci infection in sheep and goats Technical report submitted to Director, Far Eastern Regiona Research Office, American Embassy and Indian Council of Agricultural Research, Krishi Bhavan, New Delhi.

4. Laemmli, U.K. (1970). Cleavage of structural protein during the assembly of the herd of acteriophage T4. Nature (London). 227: 680-685

5. Mani,B.K, Mini,M. Jayaprakasan, V., Nair,G.K and Saseendranath,M.R. (2006). Pathogenicity of Chlamydophila abortus isolates in mice and guinea pigs. J. Vet. Anim. Sci. 37(1\&2): 32-34.

6. Markey, B.K., McNulty, M.S., Todd,D and Mackie, D.P. (1993). Comparison of ovine abortion and non-abortion isolates of Chlamydia psittaci using inclusion morphology, polyacrylamide gel electrophoresis, restriction endonuclease analysis and reactivity with monoclonal antibodies. Vet. Microbiol. 35 (1,2): 141-159.

7. Storz, J. (1971). Chlamydia induced diseases. In "Chlamydia and Chlamydia induced diseases" (C. Thomas, Ed.) Springfield, Illinois. 